\title{
Association of Caspase 8 and Caspase 10 Genetic Polymorphisms with B-cell Non Hodgkin's Lymphoma in Egypt: A Case-Control Study
}

\author{
Hanaa Hamed Arnaout ${ }^{1}$, Mervat Mamdooh Khorshied ${ }^{1}$, Ola M. Reda Khorshid ${ }^{2 *}$ and Mona Hazem El-Nagdy ${ }^{1}$
}

${ }^{1}$ Department of Clinical and Chemical Pathology, Faculty of Medicine, Cairo University, Egypt

${ }^{2}$ Department of Medical Oncology, National Cancer Institute, Cairo University, Egypt

\begin{abstract}
Background and purpose: Non-Hodgkin lymphomas are closely related diseases with distinctive morphologic, immunophenotypic, genetic, and clinical features. Genetic susceptibility studies of NHL are mandatory to identify at risk populations and to clarify important disease mechanisms. Caspase genes play a key role in regulation of apoptotic cell death, and dysregulation of this signaling pathway has been shown to participate in tumorigenesis. The current study aimed at defining the role of Caspase 8-D302H, Caspase 8-652 6N ins/del and Caspase 10-1522L genetic polymorphisms as risk factors for $\mathrm{NHL}$ and their possible role as genetic prognostic markers.
\end{abstract}

Methods: The present study included 100 Egyptian B-cell NHL patients and 100 healthy controls. Genotyping of the studied genes was performed by polymerase chain reaction-restriction fragment length polymorphism (PCRRFLP) technique. Data was analyzed using SPSS statistical package version 15.

Results: The study revealed that CASP8-D302H mutant genotypes were significantly higher in NHL patients when compared to the controls and conferred increased risk of NHL. For CASP8-652 6N ins/del and Casp10I522L, there was no statistical difference in the distribution of the different genotypes between NHL cases and the controls. Furthermore, there were no statistical differences between NHL patients harboring the wild or mutant genotypes of the studied genes as regards their response to therapy.

Conclusions: CASP8-D302H genetic polymorphism represents a genetic risk factor for NHL in Egyptian population. Hopefully, better understanding of the functional consequences of caspase genes polymorphism would provide a foundation for future studies of the possible role of these genes in lymphomagenesis.

Keywords: Caspase; Polymorphisms; Non Hodgkin’s Lymphoma

\section{Introduction}

Non-Hodgkin's Lymphomas (NHL) are closely related diseases, each involving the malignant transformation of lymphoid cells, but with distinctive morphologic, immunophenotypic, genetic, and clinical features [1,2]. In Egypt, it is the fifth most common cancer in both sexes. The incidence of non-hodgkin's lymphoma increased steadily from 1995 to 2004 particularly in the elderly population [3]. Thus, developing additional strategies for screening and prevention of nonHodgkin's lymphoma becomes mandatory.

Caspases are intracellular cysteine proteases that mediate apoptosis and are categorized as initiator caspases $(1,2,4,5,8,9,10,11$, and 12) or effector caspases (3, 6, 7, and 14) [4]. Aberrant expressions or activities are associated with many pathological conditions, including cancer [5]. Caspase 8 is a key regulator of apoptosis, an essential defense mechanism against hyper-proliferation and tumorigenesis [6]. The importance of caspase- 8 in initiating death receptor-induced apoptosis and maintaining immune homeostasis and surveillance is well established. However, little is known about genetic variants in CASP8 and their role in human cancer susceptibility [5]. Lan et al. [4] suggested that SNPs in initiator caspases as CASP8 affect lymphomagenesis. They attributed their suggestion to other biological functions mediated by these genes other than apoptosis. In particular, CASP8 plays a particular role in regulating lymphocyte homeostasis, NF-kB activation and differentiation of monocytes into macrophages, all of potential relevance to NHL aetiology. Moreover, Sun et al. [5] reported that somatic mutations of CASP8 are responsible for down regulation of CASP8 expression. Somatic mutations and genetic polymorphisms in the CASP8 gene have been reported in breast cancer, gliomas, lung cancers and multiple myeloma [7-9].
In apoptotic signal transduction initiated by death receptors and their ligands such as FAS and FASL, caspase- 8 cooperates with caspase-10 and the fas-associated protein with death domain-like apotosis regulator (CFLAR). CASP10 and CFLAR are adjacent to CASP8 in the human genome. Therefore, these three genes are strong candidate loci for cancer susceptibility owing to their important roles in immune regulation, including activation-induced cell death (AICD) of T lymphocytes [10].

Single nucleotide polymorphism in the coding region of CASP8$\mathrm{D} 302 \mathrm{H}$ has been reported. The aspartate to histidine change at residue 302 on the surface of caspase 8 is hypothesized to influence its autoprocessing or interactions with antiapoptotic molecules, such as the fas-associated protein with death domain-like apotosis regulator (CFLAR) [11]. The ins/del polymorphism (-/CTTACT, a 6bp/ del) in the promoter region of CASP8 gene was suggested to remove the stimulatory protein 1 binding site and to be associated with reduced susceptibility to many cancers including lung, esophageal, gastric, colorectal, cervical, and breast cancer [12]. Caspase 10 is homologous

${ }^{*}$ Corresponding authors: Mervat Mamdooh Khorshied, M.D, Assistant Professor of Clinical Pathology, Faculty of Medicine, Cairo University, Cairo, Egypt, Tel: +202 33037080; E-mail: mervatkhorshied@hotmail.com

Received July 10, 2012; Accepted August 08, 2012; Published August 10, 2012

Citation: Arnaout HH, Khorshied MM, Khorshid OMR, El-Nagdy MH (2012) Association of Caspase 8 and Caspase 10 Genetic Polymorphisms with B-cell Non Hodgkin's Lymphoma in Egypt: A Case-Control Study. J Cancer Sci Ther 4: 249253. doi:10.4172/1948-5956.1000150

Copyright: (c) 2012 Arnaout $\mathrm{HH}$, et al. This is an open-access article distributed under the terms of the Creative Commons Attribution License, which permits unrestricted use, distribution, and reproduction in any medium, provided the original author and source are credited. 
to caspase 8. Inherited CASP 10 mutations underline defective lymphocyte and dendritic cell apoptosis and may contribute to the pathogenesis of NHL [13].

The aim of the current study was to investigate the association of Caspase 8-D302H, Caspase 8-652 6N ins/del and Caspase 10-I522L genetic polymorphisms as risk factors for NHL and their possible role as prognostic markers for B-cell NHL in Egypt. The chosen SNPs were a common SNP in exon 9 of caspase 8 (D302H, G>C), SNP at the promoter region of caspase $8(-6526 \mathrm{~N}$ del, - /CTTACT) and a common SNP in exon 8 of caspase 10 (I522L, A>T). This combination was chosen as recommended by the National Center for Biotechnology information dbSNP database [14].

\section{Material and Methods}

\section{Study population}

This study comprised 100 adult Egyptian B-cell NHL patients and 100 age and gender matched healthy controls. Cases were selected from the Department of Medical Oncology, National Cancer institute (NCI), Cairo University, Egypt. Patients were either newly diagnosed cases or attending the NCI for follow-up. They were 40 females and 60 males and their ages ranged from 18-71 years with a mean age of 40 years. The research protocol was approved by the research Ethics committee of the Departments of Clinical pathology and Medical Oncology, Cairo University. Diagnosis of B-NHL was based on lymph node excision biopsy from the affected group of lymph nodes. Histopathological and immunohistochemical studies were done to confirm the diagnosis and for proper sub-typing according to the WHO classification [15]. Bone marrow biopsy was done for staging. The extent of the disease was categorized according to the Ann Arbor classification and the performance status was assessed using the Eastern Cooperative Oncology Group (ECOG) criteria [16]. All patients under study were subjected to full history taking with special attention to B symptoms (fever, night sweats and loss of weight), symptoms denoting site of affection, or family history of similar condition. Thorough clinical examination according to the standard sheet of hematological malignant disorders of the NCI was done with careful notation and assessment of clinical signs relevant to NHL. Radiological assessment was done for all patients for proper diagnosis and staging. Laboratory investigations included complete blood count, liver and kidney functions, serum uric acid, LDH and Beta2 microglobulin. The clinical and laboratory characteristics of NHL patients are presented in (Table $1)$.

\section{Genotyping of caspase 8-D308H, caspase 8-6N 652 ins/del and caspase 10-1522 $\mathrm{L}$}

Genomic DNA extraction from peripheral blood leucocytes was done using Gene JET Genomic DNA purification kit (Fermentas, Lithuania) following the manufacturer's instructions. DNA samples were routinely stored at $-20^{\circ} \mathrm{C}$. Genotypic analysis of the candidate genes was performed by polymerase chain reaction-restriction fragment length polymorphism (PCR-RFLP) method. The primer sequences and the restriction enzymes used are presented in (Table 2). All PCR reactions were performed in a total volume of $25 \mu$ containing 2-3 $\mu$ l genomic DNA, $12.5 \mu \mathrm{l} 2 \mathrm{X}$ Dream Taq Green PCR Master Mix, $1 \mu \mathrm{l}$ of each forward and reverse primers (20 pM) (Fermentas, Lithuania). The thermocycler programs conducted for amplifying the candidate genes and the restriction enzymes used for genotyping are presented in (Table 3). The PCR products were visualized by agarose gel electrophoresis [17].

\section{Treatment regimen for non-hodgkin lymphoma}

All patients were subjected to the standard protocol of treatment of NHL (NCI). Non- bulky $(<10 \mathrm{~cm})$ stages IA and IIA cases including extra-nodal presentations can be successfully managed by 3 to 4 cycles of a doxorubicin containing regimen (e.g. CHOP followed by involved field radiotherapy (IFRT). Cycle is repeated every 21 days. The treatment protocol was intravenous Cyclophosphamide $(750 \mathrm{mg} / \mathrm{m} 2)$, Doxorubicin $(50 \mathrm{mg} / \mathrm{m} 2)$ and Vincristine $(2 \mathrm{mg} / \mathrm{m} 2)$ at day 1 with oral Prednisone $(100 \mathrm{mg})$ as a total dose from day 1 to 5 .

\section{Response to therapy}

Complete remission (CR) was defined as normalization of clinical and radiological abnormalities, relevant laboratory data and bone marrow picture for four weeks after the last cycle of chemotherapy.

\begin{tabular}{|c|c|c|c|}
\hline \multirow{2}{*}{\multicolumn{2}{|c|}{\begin{tabular}{|l} 
Item \\
Sex (Male/Female) \\
\end{tabular}}} & \multicolumn{2}{|c|}{ NHL Patient (number-\%) } \\
\hline & & $60 / 40$ & $3: 2$ \\
\hline \multicolumn{2}{|c|}{ B- symptoms: Fever, night sweats, weight loss } & $30 / 100$ & $30 \%$ \\
\hline \multicolumn{2}{|l|}{ Lymphadenopathy } & $74 / 100$ & $74 \%$ \\
\hline \multirow{7}{*}{$\begin{array}{l}\text { Groups of lymph } \\
\text { nodes involved }\end{array}$} & Cervical & $46 / 100$ & $46 \%$ \\
\hline & Axillary & $32 / 100$ & $32 \%$ \\
\hline & Inguinal & $27 / 100$ & $27 \%$ \\
\hline & Abdominal & $17 / 100$ & $17 \%$ \\
\hline & Submandibular & $15 / 100$ & $15 \%$ \\
\hline & Para-aortic & $13 / 100$ & $13 \%$ \\
\hline & Mesenteric & $3 / 100$ & $3 \%$ \\
\hline \multicolumn{2}{|c|}{$\begin{array}{l}\text { Extranodal involvement (GIT, bone, kidney, skin } \\
\text { or liver) }\end{array}$} & $51 / 100$ & $51 \%$ \\
\hline \multicolumn{2}{|l|}{ Splenomegaly } & $36 / 100$ & $36 \%$ \\
\hline \multicolumn{2}{|l|}{ Hepatomegaly } & $23 / 100$ & $23 \%$ \\
\hline $\begin{array}{l}\text { Clinical Stage: } \\
\text { IA } \\
\text { IB } \\
\text { IIA } \\
\text { IIB } \\
\text { IIIA } \\
\text { IIIB } \\
\text { IVA } \\
\text { IVB }\end{array}$ & & $\begin{array}{c}15 / 100 \\
1 / 100 \\
12 / 100 \\
4 / 100 \\
20 / 100 \\
10 / 100 \\
22 / 100 \\
16 / 100\end{array}$ & $\begin{array}{c}15 \% \\
1 \% \\
12 \% \\
4 \% \\
20 \% \\
10 \% \\
22 \% \\
16 \%\end{array}$ \\
\hline $\begin{array}{l}\text { Performance stat } \\
\text { Score 0 } \\
\text { Score I } \\
\text { Score II } \\
\text { Score III } \\
\text { Score IV }\end{array}$ & & $\begin{array}{l}2 / 100 \\
70 / 100 \\
16 / 100 \\
9 / 100 \\
3 / 100\end{array}$ & $\begin{array}{c}2 \% \\
70 \% \\
16 \% \\
9 \% \\
3 \%\end{array}$ \\
\hline \multicolumn{2}{|c|}{$\begin{array}{l}\text { Pathological subtypes: } \\
\text { Diffuse large B-cell lymphoma (DLBCL) } \\
\text { Follicular lymphoma (FL) } \\
\text { Small lymphocytic lymphoma (SLL) } \\
\text { T-cell rich B-cell lymphoma } \\
\text { Mantle Zone Lymphoma (MZL) }\end{array}$} & $\begin{array}{l}78 / 100 \\
7 / 100 \\
7 / 100 \\
4 / 100 \\
4 / 100\end{array}$ & $\begin{array}{l}78 \% \\
7 \% \\
7 \% \\
4 \% \\
4 \%\end{array}$ \\
\hline $\begin{array}{l}\text { IPI } \\
0 \\
1 \\
2 \\
3 \\
4\end{array}$ & & $\begin{array}{l}13 / 100 \\
29 / 100 \\
35 / 100 \\
18 / 100 \\
5 / 100\end{array}$ & $\begin{array}{c}13 \% \\
29 \% \\
35 \% \\
18 \% \\
5 \%\end{array}$ \\
\hline $\begin{array}{l}\text { Response to trea } \\
\text { Complete remissic } \\
\text { Partial remission ( } \\
\text { Partial disease (PD } \\
\text { Relapse } \\
\text { Died } \\
\text { Stopped treatmen } \\
\text { Unavailable }\end{array}$ & n request & $\begin{array}{c}12 / 100 \\
14 / 100 \\
6 / 100 \\
33 / 100 \\
5 / 100 \\
9 / 100 \\
21 / 100\end{array}$ & $\begin{array}{c}12 \% \\
14 \% \\
6 \% \\
33 \% \\
5 \% \\
9 \% \\
21 \%\end{array}$ \\
\hline
\end{tabular}

IPI: International prognostic index

Table 1: The demographic characteristics of NHL patients at presentation. 
Citation: Arnaout HH, Khorshied MM, Khorshid OMR, El-Nagdy MH (2012) Association of Caspase 8 and Caspase 10 Genetic Polymorphisms with B-cell Non Hodgkin's Lymphoma in Egypt: A Case-Control Study. J Cancer Sci Ther 4: 249-253. doi:10.4172/1948-5956.1000150

\begin{tabular}{|c|c|c|c|}
\hline Gene & Primer sequence & PCR product & Reference \\
\hline CASP8-D302H & $\begin{array}{c}\text { F: 5'-CATTTTGAGATCAAGCCCCG-3' } \\
\text { R: 5'-CCCTTGTCTCCATGGGAGAGGA-3' }\end{array}$ & $132 \mathrm{bp}$ & {$[16]$} \\
\hline CASP8- $6256 \mathrm{~N}$ & $\begin{array}{l}\text { F: 5'-CTGCATGCCAGGAGCTAAGT-3' } \\
\text { R: 5'-GCCATAGTAATTCTTGCTCTGC-3' }\end{array}$ & $171 \mathrm{bp}$ & {$[17]$} \\
\hline CASP10 -1522L & $\begin{array}{c}\text { F: 5'-GAGTGGACAAACAGGGAACAAA-3' } \\
\text { R: 5'-AGAACCAACAAAAACTCTCTGCAATA-3' }\end{array}$ & $122 \mathrm{bp}$ & [16] \\
\hline
\end{tabular}

Table 2: The primer sequences applied for amplification of Caspase 8-D302H, Caspase 8-652 $6 \mathrm{~N}$ ins/del and Caspase 10-1522 $\mathrm{L}$ genes.

\begin{tabular}{|c|c|c|c|c|}
\hline Gene & Thermocycler program & Restriction enzyme & Genotypes & Restriction fragments \\
\hline CASP8-D302H & \multirow{2}{*}{$\begin{array}{c}94^{\circ} \mathrm{C} \text { for } 1 \mathrm{~min} ., 35 \text { cycles of } 94^{\circ} \mathrm{C} \text { for } 40 \mathrm{sec}, 60^{\circ} \mathrm{C} \text { for } 40 \mathrm{sec}, 7^{\circ} \mathrm{C} \text { for } \\
40 \mathrm{sec} \text {, then final extension at } 72^{\circ} \mathrm{C} \text { for } 5 \mathrm{~min} \text {. }\end{array}$} & BstUI & $\begin{array}{l}\text { Wild genotype } \\
\text { Homotype } \\
\text { Heterotype }\end{array}$ & $\begin{array}{c}132 b p \\
112+20 b p \\
132+112+20 b p\end{array}$ \\
\hline CASP8- $6256 N$ & & Bfal & $\begin{array}{l}\text { Wild genotype } \\
\text { Homotype } \\
\text { Heterotype }\end{array}$ & $\begin{array}{c}171 \mathrm{bp} \\
146+31 \mathrm{bp} \\
171+146+31 \mathrm{bp}\end{array}$ \\
\hline CASP10-1522L & $\begin{array}{c}94^{\circ} \mathrm{C} \text { for } 1 \mathrm{~min} ., 30 \text { cycles } 94^{\circ} \mathrm{C} \text { for } 40 \mathrm{sec}, 50^{\circ} \mathrm{C} \text { for } 40 \mathrm{sec}, 72^{\circ} \mathrm{C} \text { for } 40 \\
\text { sec., then final extension step at } 72^{\circ} \mathrm{C} \text { for } 5 \mathrm{~min} \text {. }\end{array}$ & Sspl & $\begin{array}{l}\text { Wild genotype } \\
\text { Homotype } \\
\text { Heterotype }\end{array}$ & $\begin{array}{c}122 b p \\
97+25 b p \\
122+97+25 b p\end{array}$ \\
\hline
\end{tabular}

Table 3: Genotyping of Caspase 8-D302H, Caspase 8-652 6 N ins/del and Caspase 10-1522L genes by PCR-RFLP assay.

\begin{tabular}{|c|c|c|c|c|c|}
\hline Gene & NHL Patients (number-\%) & Controls (number-\%) & OR & $95 \% \mathrm{Cl}$ & $P$ value \\
\hline $\begin{array}{ll}\text { CASP8 D302H } \\
\text { - } & \text { Wild genotype CC } \\
\text { - } & \text { Heterotype CG } \\
\text { - } & \text { Homotype GG } \\
\text { CG and GG }\end{array}$ & $\begin{array}{c}9(9 \%) \\
7(7 \%) \\
84(84 \%) \\
91(91 \%)\end{array}$ & $\begin{array}{c}49(49 \%) \\
6(6 \%) \\
45(45 \%) \\
(51 \%)\end{array}$ & $\begin{array}{c}\text { Reference } \\
1.179 \\
6.417 \\
9.715\end{array}$ & $\begin{array}{c}0.382-3.641 \\
3.303-12.466 \\
4.413-21.387\end{array}$ & $\begin{array}{c}0.774 \\
<0.001 \\
<0.001\end{array}$ \\
\hline $\begin{array}{ll}\text { CAS8 6N } 652 \text { ins/del } \\
\text { Wild genotype ins/ins } \\
\text { Heterotype ins/del } \\
\text { - } & \text { Homotype del/del } \\
\text { Ins/del and del/del }\end{array}$ & $\begin{array}{l}19(19 \%) \\
44(44 \%) \\
37(37 \%) \\
81(81 \%)\end{array}$ & $\begin{array}{l}20(20 \%) \\
46(46 \%) \\
34(34 \%) \\
80(80 \%)\end{array}$ & $\begin{array}{c}\text { Reference } \\
0.966 \\
1.140 \\
0.886\end{array}$ & $\begin{array}{c}0.55-1.677 \\
0.639-2.035 \\
0.508-1.546\end{array}$ & $\begin{array}{l}0.887 \\
0.658 \\
0.671\end{array}$ \\
\hline $\begin{array}{ll}\text { CASP } 10 \text { I522L } \\
\text { - } & \text { Wild genotype TT } \\
\text { Heterotype TA } \\
\text { - } & \text { Homotype AA } \\
\text { TA and AA }\end{array}$ & $\begin{array}{c}48(48 \%) \\
43(43 \%) \\
9(9 \%) \\
52(52 \%)\end{array}$ & $\begin{array}{l}45(45 \%) \\
41(41 \%) \\
14(14 \%) \\
55(55 \%)\end{array}$ & $\begin{array}{c}\text { Reference } \\
1.08 \\
0.608 \\
0.938\end{array}$ & $\begin{array}{c}0.619-1.904 \\
0.250-1.476 \\
0.466-1.889\end{array}$ & $\begin{array}{l}0.774 \\
0.268 \\
0.858\end{array}$ \\
\hline $\begin{array}{l}\text { Dual CASP8 D302H / CASP8-652 6N ins/ } \\
\text { del mutation }\end{array}$ & $74(74 \%)$ & $40(40 \%)$ & 4.269 & $2.344-7.777$ & $<0.0001$ \\
\hline $\begin{array}{l}\text { Dual CASP } 8 \text { D302H / CASP10 I522L } \\
\text { mutation }\end{array}$ & $47(47 \%)$ & $31(31 \%)$ & 1.974 & $1.108-3.517$ & 0.020 \\
\hline $\begin{array}{l}\text { Dual CASP 8-652 } 6 \mathrm{~N} \text { ins/del /CASP } 10 \\
\text { I522L mutation }\end{array}$ & $39(39 \%)$ & $40(40 \%)$ & 0.959 & $0.959-0.554$ & 0.885 \\
\hline Triple mutation & $35(35 \%)$ & $24(24 \%)$ & 1.705 & $0.921-3.157$ & 0.088 \\
\hline
\end{tabular}

p-value $<0.05=$ significant

Table 4: The frequency of CASP8- D302H, CASP8- 652 6N ins/del, and CASP10- 1522L genotypes in NHL patients and controls.

Patients were classified as having partial remission (PR) if they have at least a $50 \%$ reduction in the sum of the product of the greatest crosssectional diameters of measurable lesions. New lesions or more than $25 \%$ increase in an individual lesion over one treatment cycle was categorized as progressive disease (PD). Appearance of new lesions or the reappearance of old lesions in patients who achieved complete remission was categorized as relapse [18].

\section{Statistical analysis}

Data was analyzed using SPSS statistical package version 15. Numerical data were expressed as mean, standard deviation and range. Qualitative data were expressed as frequency and percentage. Chisquare test (or Fisher's exact test) was used to examine the relation between qualitative variables. Odds ratio (OR) and $95 \%$ confidence interval (CI) were calculated for risk estimation. A p-value less than 0.05 was considered significant.

\section{Results}

The frequency of the studied genes among NHL patients and controls are presented in Table 4. The frequency of CASP8-D302H mutant genotypes was statistically significantly higher in NHL patients when compared to the controls. Calculated risk estimation revealed that the homomutant genotype conferred six fold increased risk of NHL. For CASP8-652 6N ins/del and Casp10- I522L, there was no statistically significant difference in the distribution of the different genotypes between NHL cases and the controls. Dual mutant genotype of CASP8- D302H and CASP8- 652 6N ins/del was significantly higher among NHL patients and conferred fourfold increased risk of NHL. Dual mutant genotypes of CASP8- D302H and CASP10- I522L were significantly higher in NHL patients and conferred almost two fold increased risk of NHL. For dual mutant genotypes of CASP8-6N $652 \mathrm{ins} / \mathrm{del}$ and CASP10- I522L and triple mutant genotypes, there was no statistical difference noticed in the distribution of the mutant genotypes between the patients and the controls (Table 4). Further analysis of the influence of the studied genetic polymorphisms on the clinic-pathological characteristics of the disease revealed that there was no statistically significant difference as regards the age, gender, clinical 
and laboratory data or response to therapy between NHL patients harboring the wild or mutant genotypes (Data not shown).

\section{Discussion}

Apoptosis, a controlled process of programmed cell death plays an important role in the development and maintenance of tissue homeostasis [6], and has a principal role in the pathogenesis of malignancies when the genes controlling the apoptotic pathways are altered by mutations [19]. Previous studies have demonstrated that Caspase genes play a key role in regulation of apoptotic cell death, and dysregulation of this signaling pathway has been found to increase the risk of a number of human malignancies $[20,21]$

Searching for genes and pathways that contribute to NHL may help to identify at risk population. This would be of value in choosing therapeutic regimens that track or block these pathways to improve the future clinical practice. The current study aimed at investigating the influence of genetic polymorphisms of caspase 8 and caspase 10 on the susceptibility to B-cell NHL and the possible role of these genetic variants as prognostic markers.

Genotypic analysis revealed that CASP8-D302H GG homotype was significantly higher in NHL patients and conferred six fold increased risk of NHL. Our results are in accordance to Lan et al. [4]. Analysis of the influence of the CASP8-D302H genetic polymorphism on the clinic-pathological characteristics of the disease revealed that there was no statistically significant difference between NHL patients with wild or mutant genotypes as regards their age, gender, clinical or laboratory data or their response to therapy. Although the relapse rate was higher among NHL patients harboring the mutant genotypes, it did not reach a statistically significant level.

Genotyping of CASP8-652 6N ins/del polymorphism revealed that the frequency of CASP8-652 $6 \mathrm{~N}$ ins/del genotype was $44 \%$, while the del/del genotype was $19 \%$. These frequencies were higher than that reported by [12] in Chinese population. Different genetic background might account for this discrepancy. There was no statistical difference encountered in the distribution of the mutant genotypes between NHL patients and the controls, thus CASP8- $6526 \mathrm{~N}$ ins/del polymorphism could not be considered as a genetic risk factor for NHL in Egypt. This is in accordance with the results of Xiao et al. [12].

Genotyping of Caspase10-I522L gene revealed that the frequency of the mutant genotypes was slightly higher in NHL patients compared to controls, yet it did not reach a statistically significant level. We could not detect an association between this genetic polymorphism and susceptibility to NHL. This is in agreement with the study of Lan et al. [4]. Comparing NHL patients harboring the wild genotype and the mutant genotypes of CASP8-652 6N ins/del and Caspase10-I522L, we found no statistically significant difference between the two groups as regards their age, gender, presenting symptoms, clinical and laboratory data or their response to therapy for both genetic polymorphisms.

Combined genotype analysis revealed that co-inheritance of caspase 8-D302 $\mathrm{H}$ with either and caspase 8-652 $6 \mathrm{~N}$ ins/del or caspase 10-I522L was associated with increased risk of NHL. However, this could be attributed to the effect of caspase 8-D302H polymorphism by itself which conferred six folds increase NHL risk.

\section{Conclusion}

Caspase 8-D302H genetic polymorphism represents a genetic risk factor in the pathophysiology and the development of NHL in Egyptian population. So, better understanding of the functional consequences of caspase genes polymorphism would provide a foundation for future studies of the possible role of these genes in the lymphomagenesis, or on the response to anti-neoplastic therapy with the ultimate goal of identifying novel prevention approaches. Further studies with larger samples are required to clarify the role of this genetic polymorphism as a contributor for lymphomagenesis and to confirm its association with NHL.

\section{Author's Contributions}

Mervat Khorshied was responsible for designing of the study, provided the genotyping and performed the statistical analysis of the results; Mona Hazem collected the samples and the data of the participants; Hanaa Arnaout critically reviewed the manuscript; Ola Khorshid was responsible for the clinical assessment and follow up of the patients. All authors participate in data analysis, writing the manuscript and approved the final version of the manuscript submission.

\section{Conflict of Interest Statement}

All authors have no financial support or conflict of interest to disclose.

\section{References}

1. Morton LM, Purdue MP, Zheng T, Wang SS, Armstrong B, et al. (2009) Risk of non-Hodgkin lymphoma associated with germline variation in genes that regulate the cell cycle, apoptosis, and lymphocyte development. Cancer Epidemiol Biomarkers 18: 1259-1270.

2. Schuetz JM, Daley D, Graham J, Berry BR, Gallagher RP, et al. (2012) Genetic variation in cell death genes and risk of non-hodgkin lymphoma. PLoS One 7 e31560

3. Abdel-Fattah MM, Yassine OG (2007) Non-Hodgkin's lymphomas in Alexandria, Egypt; incidence rates and trend study (1995-2004). Eur J Cancer Prev 16: 479-485

4. Lan Q, Morton LM, Armstrong B, Hartge P, Menashe I, et al. (2009) Genetic variation in caspase genes and risk of non-Hodgkin lymphoma: a pooled analysis of 3 population- based case- control studies. Blood 114: 264-267.

5. Sun T, Gao Y, Tan W, Ma S, Shi Y, et al. (2007) A six nucleotide insertiondeletion polymorphism in the CASP8 promoter is associated with susceptibility to multiple cancers. Nat Genet 39: 605-613.

6. Wang YX, Zhao L, Wang XY, Liu CM, Yu SG (2011) Role of Caspase 8 Caspase 9 and $\mathrm{Bcl}-2$ polymorphisms in papillary thyroid carcinoma risk in Han Chinese population. Med Oncol.

7. Bethke L, Sullivan K, Webb E, Murray A, Schoemaker A, et al. (2008) The common D302H variant of CASP8 is associated with risk of glioma. Cancer Epidemiol Biomarkers Prev 17: 987-989.

8. Cox A, Dunning AM, Garcia-Closas M, Balasubramanian S, Reed MW, et al (2007) A common coding variant in CASP8 is associated with breast cancer risk. Nat Genet 39: 352-358.

9. Son JW, Kang HK, Chae MH, Choi JE, Park JM, et al. (2006) Polymorphisms in the caspase- 8 gene and the risk of lung cancer. Cancer Genet Cytogenet 169: $121-127$.

10. Thorburn A (2004) Death receptor-induced cell killing. Cell Signal 16: 139-144

11. Yin M, Yan J, Wei S, Wei Q (2010) CASP8 polymorphisms contribute to cancer susceptibility: evidence from a meta-analysis of 23 publications with 55 individual studies. Carcinogenesis 31: 850-857.

12. Xiao MS, Zhang DF, Zeng Y, Cheng YF, Yao YG (2011) Polymorhisms in the promoter region of the CASP8 gene are not associated with non-Hodgkin's lymphoma in Chinese patients. Ann Hematol 90: 1137-1144.

13. Shin MS, Kim HS, Kang CS, Park WS, Kim SY, et al. (2002) Inactivating mutations of CASP10 gene in non-Hodgkin lymphoma. Blood 99: 4094-4099.

14. Swerdlow SH, Campo E, Harris NL, Jaffe ES, Pileri SA, et al. (2008) World Health Organization Classification of Tumours of Haematopoietic and Lymphoid Tissues. IARC Press, Lyon.

15. Armitage JO (2005) Staging non-Hodgkin lymphoma. CA Cancer J Clin 55: 368-376.

16. Li C, Zhao H, Hu Z, Liu Z, Wang LE, et al. (2008) Genetic variations and haplotypes of the caspase -8 and caspase -10 genes contribute to susceptibility to cutaneous melanoma. Hum Mutat 29: 1443-1451. 
Citation: Arnaout HH, Khorshied MM, Khorshid OMR, El-Nagdy MH (2012) Association of Caspase 8 and Caspase 10 Genetic Polymorphisms with B-cell Non Hodgkin's Lymphoma in Egypt: A Case-Control Study. J Cancer Sci Ther 4: 249-253. doi:10.4172/1948-5956.1000150

17. Chatterjee K, Williamson AL, Hoffman M, Dandara C (2011) CASP8 Promoter Polymorphism is Associated with High-Risk HPV Types and Abnormal Cytology but not With Cervical Cancer. J Med Virol 83: 630-636.

18. Oken MM, Creech RH, Tormey DC, Horton J, Davis T, et al. (1982) Toxicity and response criteria of the Eastern Cooperative Oncology Group. Am J Clin Oncol 5: 649-655.

19. Thatte U, Dahanukar S (1997) Apoptosis: clinical relevance and pharmacological manipulation. Drugs 54: 511-532.
20. Wang W, Spitz MR, Yang H, Lu C, Stewart DJ, et al. (2007) Genetic variants in cell cycle control pathway confer susceptibility to lung cancer. Clin Cancer Res 13: 5974-5981.

21. Ye Y, Yang H, Grossman HB, Dinney C, Wu X, et al. (2008) Genetic variants in cell cycle control pathway confer susceptibility to bladder cancer. Cancer 112: $2467-2474$. 